\title{
EVALUASI IMPLEMENTASI KEBIJAKAN GURU PENDIDIKAN AGAMA (GPA) PADA SEKOLAH UMUM DI PROVINSI BALI
}

\section{EVALUATION OF POLICY IMPLEMENTATION OF TEACHERS OF RELIGIOUS EDUCATION (GPA) IN PUBLIC SCHOOLS IN BALI PROVINCE}

\author{
Abdul Kadir Ahmad, Lisa'diyah Ma'rifataini \\ Pusat Penelitian dan Pengembangan Kementerian Agama RI \\ Jl. M.H. Thamrin No.6 Jakarta Pusat \\ Email:lisa.litbang@gmail.com
}

Naskah Diterima: 6 Mei 2020; Direvisi: 5 Desember 2020; Disetujui: 8 April 2021

\begin{abstract}
Crucial issues with religius education teachers (GPA) policies are related to coaching, career development, welfare and recruitment. This research approach is qualitative with descriptive type. Data collection uses in-depth interviews, participatory observations, and document studies. The purpose of this study was to determine the implementation of GPA policies on the four problems above, problems and solutions. The informants of this study were the Kasi at the Education Office, the Head of the Provincial Government, the Head of the Division and the Kasi at the Ministry of Religion, PA Supervisors and PA Teachers. The results showed that the GPA guidance policy was not optimal due to funding constraints, the limited number of supervisors covering very large coverage areas. Regarding career development, GPAs experience difficulties in writing scientific papers and require seminars or competency tests when they are promoted from IV / A to IV / B. Regarding welfare, non-PNS GPAs are constrained from participating in certification and inpassing because they have to include a decree from the Mayor / Regent and GPA who have not been certified due to limited quota There are three types of religious teachers in schools, namely those appointed by the Ministry of Religion, the Regional Government, and the Education Office, where the GPA data is always different and there is no coordination. In order to meet the lack of GPA in schools, the Ministry of Religion needs to appoint GTT religious teachers or contract teachers who are funded by the APBN, just as the Regional Government appoints GTT religious teachers who are funded by the $A P B D$.
\end{abstract}

Keywords: Bali; Evaluation; Policy; Public school; Religious education teacher

\begin{abstract}
Abstrak
Masalah krusial kebijakan Guru Pendidikan Agama (GPA) adalah terkait pembinaan, pengembangan karier, kesejahteraan dan rekrutmen. Pendekatan penelitian ini kualitatif dengan tipe Deskriptif. Pengumpulan data menggunakan in-depth interview, participatory observation, dan document studies. Tujuan penelitian ini adalah untuk mengetahui implementasi kebijakan GPA terhadap empat masalah di atas, problematika dan solusi. Informan penelitian ini adalah Kasi pada Dinas Pendidikan, Kabid di Pemda Provinsi, Kepala Bidang dan Kasi di Kemenag, Pengawas PA dan Guru PA. Hasil penelitian menunjukkan bahwa kebijakan pembinaan GPA belum optimal karena terkendala pendanaan, keterbatasan jumlah pengawas yang Coverage areas sangat luas. Terhadap pengembangan karier, GPA mengalami kesulitan dalam penulisan karya tulis ilmiah dan keharusan seminar atau uji kompetensi ketika kenaikan pangkat dari IV/A ke IV/B. Terkait kesejahteraan, GPA non PNS terkendala untuk mengikuti sertifikasi dan inpassing karena harus menyertakan SK dari Walikota/Bupati dan GPA yang belum sertifikasi karena kuota terbatas. Terdapat tiga jenis guru agama di sekolah yakni diangkat oleh Kemenag, Pemda, dan Dinas Pendidikan, di mana data GPA selalu berbeda dan belum ada koordinasi. Guna terpenuhi kurangnya GPA di Sekolah, Kemenag perlu mengangkat guru agama GTT atau guru kontrak yang dibiayai oleh APBN, seperti halnya Pemda mengangkat guru agama GTT yang dibiayai APBD.
\end{abstract}

Kata kunci: Bali; Evaluasi, Guru pendidikan agama; Kebijakan; Sekolah umum 


\section{PENDAHULUAN}

Salah satu prinsip Good Governance adalah adanya kebijakan yang membantu untuk melayani dan memudahkan masyarakat. Sebagian dari indikator kebijakan ini adalah berjalannya prinsip efisiensi, akuntabilitas, efektivitas dan pelayanan prima, sehingga masyarakat sebagai penerima dan sekaligus objek dari kebijakan tersebut terlayani secara optimal (Pemkab Buleleng, 2017). Dalam pelayanan pendidikan agama (untuk semua agama) di sekolah sebesar 0.81, yang hal ini menunjukkan bahwa ketersediaan layanan guru pendidikan agama belum penuh (100\%) (Hayadin, 2018). Selain itu, kebijakan yang dibuat oleh pemerintah bertujuan untuk memberikan payung hukum atas segala aspek program yang dijalankan. Penerima manfaat sekaligus objek dari kebijakan tersebut yaitu masyarakat yang membutuhkan regulasi sebagai perlindungan atas hak dan kewajibannya terkait objek regulasi atau kebijakan tersebut (Arisaputra, 2013). Namun demikian, ada hierarki regulasi yang perlu diperhatikan mulai dari yang paling tinggi hingga yang terendah. Di mana regulasi yang paling rendah harus mengikuti dan atau tidak boleh bertentangan dengan regulasi di atasnya. Apapun kebijakan memiliki referensi kepada regulasi yang lebih tinggi di atasnya, termasuk regulasi tentang Pendidikan Agama Islam.

Kebijakan terkait Pendidikan Agama merujuk kepada UU No. 20 Tahun 2003 tentang Sistem Pendidikan Nasional yang diturunkan menjadi Peraturan Pemerintah No. 55 tahun 2007 tentang Pendidikan Agama dan Pendidikan Keagamaan. Turunan dari PP 55 tahun 2007 ini adalah Permenag No. 16 Tahun 2010 yang menjadi payung hukum tentang Pengelolaan Pendidikan Agama di Sekolah yang operasionalnya berada di Kementerian Agama. Namun faktanya regulasi pendidikan agama khususnya pada sekolah umum, masih harus merujuk kepada regulasi yang berkaitan dan dikeluarkan oleh Kementerian Pendidikan.

Dalam tataran realitas di lapangan, ada beberapa problematika yang ditemukan terkait kebijakan di bidang pendidikan agama dengan implementasi di lapangan. Sebagai contoh beberapa kebijakan terkait rekrutmen Guru Pendidikan Agama berada pada kewenangan
Pemerintah Daerah dan Kementerian Agama. Berdasarkan Undang-Undang No. 14 Tahun 2005 kewenangan pengadaan guru juga berada di pemerintah daerah baik di tingat kabupaten dan provinsi. Namun demikian, kewenangan tersebut telah ditindaklanjuti dengan Surat Keputusan Bersama (SKB) lima menteri. Dan bagi Kementerian Agama terkait rekrutmen guru pendidikan agama bisa mengacu kepada PMA No. 16 Tahun 2010 di mana kewenangan pengangkatan guru pendidikan agama bisa dilakukan oleh kementerian agama (Hayadin, 2012). Dan menurut Lisa'diyah untuk PNS ada yang diangkat oleh Kementerian Agama (Kemenag), Dinas Pendidikan dan Pemerintah Daerah (Pemda). Guru Pendidikan Agama (GPA) non PNS diangkat oleh yayasan dan walikota/bupati. Pengangkatan PNS GPAI oleh Pemda ini dapat menimbulkan permasalahan dalam pengorganisasian dan pembinaan yang menjadi kewenangan Kementerian Agama. Hal inilah yang menyebabkan Kementerian Agama menginginkan pengangkatan Guru Agama berada di bawah kewenangannya (Ma'rifataini, 2018).

Tidak hanya guru pendidikan agama Islam saja, guru pendidikan agama lain pun demikian, seperti hal untuk rekrutmen guru pendidikan agama Hindu adalah Kementerian Agama, Diknas dan Pemda untuk PNS, sedang non PNS diangkat oleh Yayasan dan walikota/Bupati (Jaman, 2019). Kebijakan lain yang sulit untuk dilaksanakan adalah pengembangan karier Guru PA dan Pengawas PA. Guru PA yang diangkat Kementerian Agama sulit untuk mengembangkan kariernya di sekolah umum. Padahal ada payung hukum yang memungkinkan Guru PA yang diangkat Kemenag bisa mengembangkan karir menjadi kepala sekolah.

Terkait pembinaan Guru Pendidikan Agama pun sama, minimnya anggaran Kementerian Agama menyebabkan akses Guru PA untuk mendapatkan pembinaan dalam bentuk pengembangan profesionalitas keguruannya terhambat. Sementara Dinas Pendidikan yang sebenarnya juga memiliki tugas yang sama untuk membina Guru PA (baik guru agama Islam, Kristen, Katolik, Hindu dan Budha) beralasan bahwa Guru PA pembinaannya berada di bawah kewenangan 
Kementerian Agama. Termasuk di dalamnya terkait kesejahteraan Guru Pendidikan Agama yang terkendala aturan. Sebagai contoh adalah akses Guru PA untuk mendapatkan kesempatan disertifikasi atau mengikuti inpassing, kebijakan yang ada, tidak mampu mengakomodir kemudahan akses untuk GPA, mengakses untuk mengikuti sertifikasi atau inpashing tersebut. Berdasarkan beberapa permasalahan tersebut, maka penting dilakukan penelitian "Evaluasi Implementasi Kebijakan Guru Pendidikan Agama (GPA) di Sekolah”. Penelitian ini melihat kebijakan yang "diduga" bermasalah atau menimbulkan masalah pada tataran implementasi di lapangan. Penelitian ini difokuskan pada daerah minoritas muslim yaitu di Provinsi Bali.

Rumusan masalah dalam penelitian ini adalah melihat; 1) Bagaimana tingkat pemahaman pemangku kebijakan dan pelaksana terhadap kebijakan pembinaan, pengembangan karier, kesejahteraan dan rekrutmen Guru pendidikan agama. 2) Bagaimana implementasi kebijakan guru pendidikan agama tersebut. 3) Apa problematika yang dihadapi dalam mengimplementasikan kebijakan-kebijakan Guru Pendidikan Agama. Dan 4) bagaimana solusi terhadap problematika kebijakan Guru Pendidikan Agama di sekolah.

Penelitian ini bertujuan untuk mengetahui implementasi kebijakan pengelolaan Guru Pendidikan Agama di sekolah, problematika dan solusinya. Manfaat dari penelitian ini, secara akademik bisa melengkapi kajian-kajian yang sudah ada serta memperkaya pengetahuan tentang pengelolaan GPA di sekolah. Secara praktis, penelitian ini menjadi bahan rujukan dan pertimbangan dalam merumuskan kebijakan Direktorat Pendis Kementerian Agama pengelolaan GPA di sekolah.

\section{KAJIAN TEORI \\ Evaluasi Kebijakan}

Pada hakikatnya perumusan kebijakan merupakan proses terus menerus, oleh karenanya proses perumusan kebijakan sering disebut sebagai lingkaran kebijakan yang berputar terus menerus. Secara formal, evaluasi merupakan tahap akhir dari sebuah proses pembuatan kebijakan. Meskipun demikian, dari evaluasi ini dihasilkan masukan-masukan guna penyempurnaan kebijakan atau perumusan kebijakan selanjutnya. Dengan begitu, proses formulasi kebijakan menjadi mirip roda atau spiral yang berputar tiada akhir. Banyak pakar kebijakan mengistilahkan kondisi tersebut di atas dengan menyatakan bahwa kebijakan berakhir dengan, dan sekaligus berawal dari "evaluasi" (Hasbullah, 2015).

Evaluasi merupakan tahapan akhir dari sebuah proses kebijakan, merupakan penilaian mengenai apa yang telah terjadi sebagai akibat pilihan dan implementasi kebijakan, dan apabila dipandang perlu, dapat dilakukan perubahan terhadap kebijakan yang telah dilakukan. Menghasilkan evaluasi yang akurat bukanlah pekerjaan mudah, apabila untuk mengubah kebijakan bila ditemukan kesalahan yang memerlukan perbaikan segera.

Secara umum evaluasi didefinisikan sebagai proses mengumpulkan informasi mengenai suatu obyek menilai suatu obyek, dan membandingkannya dengan kriteria, standar, dan indikator ('Evaluasi Kebijakan Pelaksanaan Reward dan Punishment Aparatur Sipil Negara di Kota Bitung', 2019). Oleh sebab itu, evaluasi kebijakan dilakukan untuk mengetahui seberapa besar sebuah kebijakan dapat mencapai tujuan-tujuannya, memberi panduan kepada pelaksana kebijakan mengenai seberapa lancar perjalanan atau proses kebijakan tersebut diimplementasikan.

Dengan demikian evaluasi kebijakan pada dasarnya merupakan alat untuk mengumpulkan dan mengelola informasi mengenai program atau pelayanan yang diterapkan. Evaluasi kebijakan menyediakan data dan informasi yang bisa dipergunakan untuk menganalisis kebijakan dan menunjukkan rekomendasirekomendasi bagi perbaikan-perbaikan yang diperlukan agar implementasi kebijakan berjalan efektif sesuai kriteria yang ditetapkan.

Jadi evaluasi implementasi kebijakan diperlukan untuk memberikan penjelasan dan penilaian kelayakan, keterlaksanaan, dan keberhasilan pencapaian tujuan kebijakan termasuk mengidentifikasi berbagai kendala selama proses implementasi kebijakan berlangsung. Hasil evaluasi implementasi kebijakan dapat dijadikan sebagai pertimbangan dalam pengambilan keputusan mengenai kelanjutan, perbaikan serta penyempurnaan 
kebijakan penataan guru agama pada masa yang akan datang.

Menurut Behrstock dan Clifford (2010) pemenuhan kebutuhan guru merupakan bagian integral pemenuhan standar pelayanan pendidikan di sekolah. Karena guru merupakan aspek penting dalam pembelajaran yang terjadi di dalam kelas, penataan dan pemerataan guru penting dilakukan guna memastikan bahwa semua siswa memiliki kesempatan sama untuk belajar. Sedangkan (Adamson and DarlingHammond, 2012), menjelaskan tingkat distribusi dalam pemerataan guru menyangkut perbedaan proporsi guru dalam memenuhi standar-standar kualifikasi di sekolah.

\section{Implementasi Kebijakan}

Beberapa pakar menjelaskan bahwa proses perumusan kebijakan publik selalu dan harus memperhatikan beberapa karakteristik penting agar dapat mencapai sasaran kebijakan yang dituangkan dalam tahapan implementasi kebijakan (Muadi, MH \& Sofwani, 2016). Implementasi kebijakan merupakan proses yang sangat menentukan sekaligus menegangkan. Proses ini menjadi penting disebabkan akhir dari semua kebijakan yang sudah diambil selalu pada tahap implementasi. Seandainya rumusan kebijakannya sudah dibuat sangat bagus namun tidak ada tindak lanjut berupa implementasi, atau sulit untuk diimplementasikan atas kebijakan yang sudah dirumuskan tersebut, merupakan usaha yang sia-sia yang tidak ada artinya (Hasbullah, 2015).

Menurut Fattah (2012) bahwa kebijakan publik mengacu pada semua wilayah tindakan pemerintah yang membentang dari kebijakan ekonomi hingga kebijakan yang biasanya merujuk pada kebijakan sosial termasuk pendidikan, kesehatan, dan wilayah sejahtera lainnya.

Kebijakan pendidikan khususnya kebijakan tentang guru agama setidaknya harus memenuhi tantangan dan tuntutan global dan perkembangan zaman sebagai yang diungkapkan oleh Fattah \& Latifah (2012: 145) bahwa analisis kebijakan pendidikan menggambarkan bagaimana negara merencanakan dan menuju pada prioritas pendidikan, kemudian hasil analisis tersebut harus dijelaskan oleh adanya faktor-faktor global kebijakannya.

Mead (2015:1) mengemukakan bahwa the product of policy analisis is device. Specifically, it is advice that inform some public policy decision. Jadi analisis kebijakan publik lebih merupakan bahan pertimbangan atau nasehat untuk pembuat kebijakan yang berisi tentang masalah yang dihadapi, dan juga berbagai alternatif kebijakan yang mungkin bisa diambil dengan berbagai penilaian berdasarkan tujuan penilaian.

Maka dapat dikatakan bahwa studi implementasi kebijakan dibagi ke dalam tiga generasi menurut fokus kajian dan para teoritisnya. Presmann \& Wildavsky dan Hangrove dianggap mewakili sebagai generasi pertama penganjur studi implementasi kebijakan. Kajian implementasi mereka memfokuskan pada bagaimana keputusan otoritas tunggal dapat dilaksanakan atau tidak dilaksanakan (Nurudin, 2017)

Sementara itu, Grindle (2017) merumuskan implementasi sebagai proses umum tindakan administratif yang dapat diteliti pada tingkat program tertentu, sebagai upaya untuk mengatasi beragam problem mengimplementasi kebijakan itu sendiri, Grinde mengatakan:

"We have tried to resolve this problem by considering implementation to be a general process of administrative action that can be investigated at the specific program level. Its success or failure can be evaluated in terms of the capacity actually to deliver programs as designed".

\section{Kebijakan Guru Pendidikan Agama}

Kebijakan guru PA yang dimaksud dalam penelitian ini adalah termasuk kebijakan publik, karena dibuat oleh pemerintah dan memberikan dampak yang besar dan luas pada publik (masyarakat). Beragam definisi tentang konsep kebijakan publik dapat ditarik kesimpulan bahwa terdapat dua pendapat yang mengemuka. Pertama, pendapat yang memandang bahwa kebijakan publik identik dengan tindakantindakan yang dilakukan pemerintah. Pendapat ini cenderung beranggapan bahwa semua 
tindakan yang dilakukan oleh pemerintah pada dasarnya dapat disebut sebagai kebijakan publik. Kedua, pendapat yang memusatkan perhatian pada implementasi kebijakan (policy implementation). Pandangan yang pertama melihat bahwa kebijakan publik merupakan keputusan-keputusan pemerintah yang mempunyai tujuan atau sasaran tertentu, dan pandangan yang kedua beranggapan bahwa kebijakan publik mempunyai akibat-akibat atau dampak yang dapat diramalkan atau diantisipasi sebelumnya (Sutapa, 2008).

Pertimbangan rasional penelitian kebijakan di bidang Pendidikan ini adalah Pertama: kebijakan Pendidikan berdampak luas untuk seluruh masyarakat. Kedua, alokasi dana untuk sektor Pendidikan sangat besar. Sehingga efektivitas dan ketercapaian hasil perlu mendapat perhatian. Ketiga, penerima manfaat dari kebijakan adalah masyarakat luas (Purnama, 2010).

Efektivitas kebijakan Pendidikan di lapangan membutuhkan informasi dan data yang sistematis dan ekstensif sehingga implementasi kebijakan tersebut berjalan dengan efisien dan efektif. Sehingga penelitian kebijakan ini dimaksudkan sebagai upaya penelitian untuk mendukung kebijakan dan analisis untuk membantu pengambil kebijakan merumuskan masalah yang dihadapi atas sebuah kebijakan dan merumuskan rekomendasi atas problem yang dihadapi dari implementasi kebijakan tersebut.

Kebijakan terkait pendidikan termasuk pendidikan agama selalu keluar atau dikeluarkan dari beberapa instansi. Kebijakan tersebut ada yang berkaitan langsung dengan pendidikan agama dan ada juga yang memberikan pengaruh langsung terhadap pendidikan agama. Sebagai contoh, Surat Edaran Sekjen Kemendikbud Nomor 088209/A.C5/KP/2011 yang menyatakan bahwa GTT yang tidak dibiayai oleh APBN/APBD tidak boleh mengikuti sertifikasi. SE ini menyebabkan seluruh Guru Pendidikan Agama Non PNS harus mendapatkan Surat Keputusan sebagai Guru Honor di sekolah dari Walikota atau Bupati c.q. Kepala Dinas. Dan hal ini juga berimbas kepada Guru Pendidikan Agama Non PNS yang Tunjangan Profesi Gurunya (TPG) dibayarkan oleh Kemenag.
Kemenag tidak berani untuk membayarkan TPG GPAI non PNS berdasarkan aturan tersebut serta Edaran dari Kementerian Keuangan terkait pembayaran TPG.

Kebijakan terkait Guru Pendidikan Agama, ini akan dipetakan berdasarkan empat variable atau sebagai ruang lingkup, yaitu Pembinaan, Pengembangan Karier, Kesejahteraan dan Rekrutmen. Pembinaan meliputi dimensi peningkatan profesionalitas Guru Pendidikan Agama. Aspek Pengembangan Karier meliputi kenaikan pangkat golongan dan jabatan untuk Guru Pendidikan Agama Aspek kesejahteraan meliputi: sertifikasi, inpassing, insentif bagi Guru Pendidikan Agama Non PNS di sekolah umum, dan Tunjangan Kinerja (Tukin) bagi Guru Pendidikan Agama PNS di sekolah umum. Sementara rekrutmen terkait institusi yang berhak untuk mengangkat Guru Pendidikan Agama dan mekanisme koordinasi antar Lembaga.

\section{Pengertian Sekolah Umum}

Yang dimaksud Sekolah Umum pada penelitian ini adalah pendidikan pada jenjang dasar yaitu Sekolah Dasar (SD) dan Sekolah Menengah Pertama (SMP), sedang untuk jenjang atas yaitu Sekolah Menengah Atas (SMA) dan Sekolah Menengah Kejuruan (SMK). Sekolah-sekolah umum ini dikelola oleh Kementerian Pendidikan dan Kebudayaan.

\section{METODOLOGI}

Penelitian ini menggunakan pendekatan kualitatif, dengan tipe penelitian deskriptif. Penelitian dengan tipe deskriptif adalah penelitian yang pemecahan masalah dengan menggambarkan keadaan subjek/objek penelitian pada saat sekarang berdasarkan fakta-fakta yang tampak. Secara singkat dapat dikatakan bahwa penelitian deskriptif merupakan langkah-langkah melakukan representatif objek penelitian tentang gejalagejala yang terdapat pada masalah penelitian (Hadari, 2019).

Tipe penelitian deskriptif penelitian ini didasarkan pada cakupan peraturan yang sangat luas, sehingga pemilihan metode ini dapat menjelaskan secara rinci dan menggambarkan secara jelas permasalahan yang muncul dalam 
mengimplementasikan kebijakan PA ditingkat pemahamannya, implementasinya, permasalahannya, serta solusinya pada aspek pembinaan, pengembangan karier dan kepangkatan, kesejahteraan dan rekrutmen,

Pengumpulan data Penelitian dilakukan melalui wawancara mendalam, pengisian kuesioner (daftar isian) kepada pelaksana (guru agama) dan pemangku kebijakan (Kepala Bidang Dinas Pendidikan, Pemda Provinsi; Kepala Bidang Pendidikan Agama Kemenag di tingkat Provinsi/bimas-bimas (Islam, Kristen, Katolik, Khonghucu, Hindu, dan Buddha), Kasi di Kemenag Kab/kota).

Untuk memperoleh hasil yang maksimal, penulis menggunakan analisis diskrepansi. Uji analisis diskrepansi bertujuan untuk mengetahui apakah terdapat perbedaan nyata (kesenjangan) antara standar acuan dengan pelaksanaan standar proses oleh tenaga pendidik pada satuan Pendidikan (Geriani, Suarni and Mertasari, 2019). Dengan teknik ini, maka rumusan desain (rumusan ideal) sesuai bunyi peraturan kebijakan akan dibandingkan dengan dasolen (kenyataan di lapangan) yang dialami/dipraktikkan oleh implementator.

Penelitian ini dilakukan di Provinsi Bali, sampel yang dijadikan obyek adalah guru agama di 3 (tiga) Kabupaten/Kota yaitu Kota Denpasar, Kab. Badung dan Kab Giannyar. Masing-masing Kab/Kota diambil 10 sekolah yang memiliki beragam guru agama dan masing-masing Guru agama diberi kuesioner untuk diisi.

Sasaran sekolah yang dijadikan sampel adalah 30 lembaga dari $3 \mathrm{Kab} / \mathrm{Kota}$, namun lembaga yang dikunjungi peneliti hanya 9 lembaga (jenjang SD 3 lembaga, SMP 3 lembaga dan SMA/K 3 lembaga) untuk melakukan wawancara dengan guru agamanya. Penelitian dilakukan selama 20 hari pada bulan April 2019, dan hasil penelitian diseminarkan pada tanggal 29 Agustus 2019 di Hotel Santika Teras Kota Serpong.

\section{HASIL DAN PEMBAHASAN}

\section{Gambaran Umum Masyarakat Bali}

Berdasarkan data dari Badan Pusat Statistik Provinsi Bali sensus penduduk tahun 2010, yang di-update 15 Februari 2018, Jumlah penduduk berdasarkan agama di Provinsi Bali sebesar 3.890.757 jiwa, penduduk terbesar di Provinsi ini berada di Kota Denpasar. Adapun Provinsi ini terdiri dari 8 kabupaten dan 1 kota.

Bila di lihat dari besaran agama yang paling banyak di anut, sebagian besar penduduk provinsi Bali memeluk agama Hindu (83,5\%), yang berikutnya adalah Agama Islam $(13,45 \%)$, Kristen (1,7\%), Katolik (0,8\%), dan Budha $(0,5 \%)$ dan yang beragama Khonghucu hanya $(0,01 \%)$. Agama Hindu menjadi mayoritas di semua kabupaten dan kota, sedangkan Agama Islam dengan jumlah besar di Provinsi ini ada di Kota Denpasar, Kabupaten Badung, Jembrana dan Buleleng, Agama Kristen, Katolik dan Budha dengan populasi besar ada di Kota Denpasar, dan Kabupaten Badung (Badan Pusat Statistik Povinsi Bali, 2018).

\section{Gambaran Umum Lembaga Pendidikan di Provinsi Bali}

Secara keseluruhan jumlah lembaga sekolah umum di sembilan Kab/Kota Provinsi Bali pada tahun ajaran 2018-2019 sebanyak 2.891 lembaga, yang berstatus Negeri sebanyak 2.591 lembaga dan yang berstatus swasta sebanyak 300 lembaga. Apabila dilihat per jenjang pendidikan, yaitu SD Negeri sebanyak 2.205 lembaga, dan SD Swasta sebanyak 76 lembaga SD. Untuk jenjang SMP berstatus Negeri berjumlah 265 lembaga dan 81 lembaga berstatus swasta. Jenjang SMA yang berstatus negeri 75 lembaga dan berstatus swasta 60 lembaga. Adapun Jenjang SMK yang berstatus negeri 46 lembaga dan swasta 83 lembaga (Badan Pusat Statistik Povinsi Bali, 2019)

\section{Gambaran siswa berdasarkan agama di Provinsi Bali}

Masyarakat Bali mayoritas beragama Hindu $(83,4 \%)$, jumlah lembaga pendidikan sekolah umum (2.591 lembaga) dengan jumlah siswa sebanyak 402.514. Apabila dilihat jumlah siswa berdasarkan agama, yang terbanyak adalah siswa yang beragama Hindu 345.554 $(86 \%)$, Siswa yang beragama Islam 42.490 (11\%), Siswa beragama Kristen 7.833 (2\%), Siswa beragama Katolik 4.064 (1\%), dan Siswa yang beragama Buddha $2.520(0,6 \%)$, Siswa yang beragama Khonghuchu 53 (0\%). 


\section{Gambaran Guru Pendidikan Agama di Provinsi Bali}

Dengan melihat banyaknya masyarakat beragama Hindu, dan Siswa juga banyak yang beragama Hindu wajar kalau jumlah guru agama di provinsi Bali terbanyak adalah guru agama Hindu, baru diikuti guru agama Islam, Kristen, Katolik baru Buddha, sebagaimana jumlah guru agama seperti pada Tabel 1.

Tabel 1. Jumlah Guru Pendidikan Agama (PNS dan Non PNS) dan jumlah siswa berdasarkan Agama di Provinsi Bali

\begin{tabular}{llllllll}
\hline Agama & Hindu & Islam & Katolik & Kristen & Budha & Khonghucu & Jumlah \\
\hline Guru PNS & 3.737 & 392 & 20 & 35 & 27 & 0 & 4.211 \\
& $(89 \%)$ & $(9,3 \%)$ & $(0,5 \%)$ & $(0,8 \%)$ & $(0,6 \%)$ & $(0 \%)$ & $(100 \%)$ \\
\hline Guru Non PNS & 1.368 & 165 & 34 & 67 & 15 & 0 & 1.649 \\
& $(83 \%)$ & $(10 \%)$ & $(2,1 \%)$ & $(4,1 \%)$ & $0,6 \%)$ & $(0 \%)$ & $(100 \%)$ \\
\hline Jumlah Siswa & 345.554 & 42.490 & 4.064 & 7.833 & 2.520 & 53 & 402.514 \\
& $(86 \%)$ & $(10,1)$ & $(1 \%)$ & $(2 \%)$ & $(0,6 \%)$ & $(0 \%)$ & $(100 \%)$ \\
\hline
\end{tabular}

Keterangan: Data diperoleh dari Pendis dan Ditjen bimas ( Kristen, Katolik, Hindu, Buddha dan Khonghucu) Kantor Wilayah Kementerian Agama Provinsi Bali Tahun 2019

\section{Kebijakan Pembinaan Guru Pendidikan Agama}

Dengan adanya PP 55 Tahun 2007 Pasal 3 ayat 2 tentang Pengelolaan pendidikan agama dilaksanakan oleh Menteri Agama. Para pemangku kebijakan di lingkungan Kementerian Agama memahami pengelolaan pembinaan dan sertifikasi guru pendidikan agama baik guru agama yang diangkat kemenag atau pemda menjadi urusan Kementerian Agama. Para pemangku kebijakan terutama di lingkungan Pemda, Dinas pendidikan pada umumnya tidak memahami secara rinci apa isi dari PP tersebut. Sedangkan para pelaksana yakni guru dan pengawas Pendidikan agama pada umumnya mengetahui tetapi hanya sekilas.

Dalam implementasinya, peraturan yang ada pembinaan guru agama seharusnya dilakukan oleh Kementerian agama sebagai landing sektornya. Pemda provinsi Bali menyadari karena minimnya pengawas PA dan anggaran kemenag untuk pembinaan, sehingga pemda tidak menunggu yang dilakukan oleh Kemenag saja. Pemda Provinsi Bali juga melakukan pembinaan guru PA yang mulai dianggarkan tahun 2019 ini, karena sesuai Visi Misi Gubernur Bali Sekarang di antaranya adalah mewujudkan Bali yang berbudaya yang dalam hal ini agama menjadi penting sehingga peranan guru agama juga menjadi penting, sehingga program pembinaan guru-guru agama termasuk juga program prioritas pada tahun 2019 ini.

Terkait Pembinaan Guru agama di Kemenag, selama ini Pola pembinaan GPA masih bersifat top down dalam arti kegiatan pembinaan hanya dilakukan bila ada kegiatan dari pusat. Harka Maya menyampaikan salah satu cara pembinaan guru melalui kelompok profesi dalam peningkatan kapasitas dan profesionalitas yaitu melalui kegiatan KKG dan MGMP. Sementara di Bali fungsi Kelompok Kerja Guru (KKG) dan Musyawarah Guru Mata Pelajaran (MGMP) PAI di semua jenjang kurang optimal disebabkan pola menunggu bola dari pengurus KKG/MGMP PAI dalam menjalankan kegiatan, walaupun sebenarnya KKG dan MGMP PAI memiliki pertemuan rutin di setiap wilayah dalam tenggang waktu satu minggu dan satu bulan. Maka diperlukannya himbauan dari pusat kepada setiap daerah untuk melakukan penguatan KKG dan MGMP menjadi Sumber belajar.

Yang menjadi problem pembinaan yang dilakukan melalui Diklat Keagamaan belum menjangkau seluruh agama, pembinaan yang dilakukan oleh Balai diklat keagamaan meski mengatakan seluruh agama namun selama ini hanya menjangkau guru agama yang mayoritas Agama Hindu dan Agama Islam itu pun tidak bisa mencakup banyak guru agama, karena memiliki banyak kabupaten yang diwakili 1 atau 2 orang GPA. Selama ini untuk agama Kristen, Katolik sangat jarang, guru agama 
Buddha dan Khonghucu tidak pernah terlayani. Di Diklat Bali seringkali program diklat bukan Multi Agama tetapi seringkali hanya Diklat pada mayoritas Agama. Di Diklat Bali yang sering terjadi Diklat Guru pendidikan agama Hindu dan Diklat pendidikan agama Islam, untuk guru agama Kristen dan khatolik, Buddha dan Khonghucu selama ini tidak pernah terkaver. (Wawancara dengan pengawas agama Kristen, di Kantor Balai Litbang Denpasar,2019)

\section{Menurut Pengawas Agama Kristen,} Pembinaan guru pendidikan agama Kristen/katolik seharusnya dari Kemenag dan dari Balai Diklat. Namun Pembinaan selama ini hanya dari masing-masing bimas dan gereja, yang pelaksanaannya secara rutin setiap tahun. Di Diklat Bali sering kali program diklat bukan Multi Agama tetapi sering kali hanya Diklat pada mayoritas Agama. Di Diklat Bali yang sering terjadi Diklat Guru pendidikan agama Hindu, dan Diklat pendidikan agama Islam, yang guru agama Kristen dan katolik selama ini tidak terkaver.

Wawancara dengan pengawas agama Hindu (Rusta,2019), Program pembinaan, setiap tahun selalu dilakukan oleh kanwil dan itupun tergantung anggaran yang ada, untuk guru pendidikan agama kemungkinannya/ peluangnya sangat kecil, karena yang diutamakan guru umum dan melalui pemberdayaan KKG dan MGMP juga anggaran dari kanwil hampir tidak ada. Untuk mengambil nilai pengembangan diri yang seharusnya diambil dari balai diklat keagamaan, sementara balai diklat jarang melibatkan guru agama, seringnya guru mata pelajaran umum.

Pembinaan guru pendidikan agama seharusnya dibina oleh pengawas guru agama di sekolah. Di Provinsi Bali jumlah pengawas PA disekolah jumlahnya sangat minimal terutama bagi pengawas yang agamanya minoritas dan bahkan tidak disediakan pengawas guru agama tersebut, yaitu pengawas guru agama Budha, Pembinaan guru pendidikan agama Kristen/katolik seharusnya dari Kemenag dan dari Balai Diklat. Namun Pembinaan selama ini hanya dari masing-masing bimas dan gereja, yang pelaksanaannya secara rutin setiap tahun.

Kebijakan Karier Guru Pendidikan Agama
Para Pemangku Kebijakan baik dari Pemda maupun Kemenag telah memahami peraturan-peraturan tentang karier dan kenaikan pangkat untuk guru dan pengawas. Dan pelaksana yaitu Pengawas/Guru agama pada dasarnya juga paham terhadap dasar-dasar pengembangan karier dan pengangkatan Pengawas dan Guru PA, karena hal itu merupakan penghargaan dalam melaksanakan tugas yang selalu dicari. Sebagai dasar kenaikan pangkat, yaitu KMA no. 2 tahun 2012, Permenpan RB no.21 tahun 2010, dan permendikbud 143 tahun 2014.

Dalam implementasinya, Karier guru dalam Permenpan RB pasal 23 yang mengatakan penilaian angka kredit ke pangkat IV/b atau ke IV c seterusnya adalah harus melalui kemendikbud. Bagi guru agama yang diangkat oleh Kemenag mengalami kesulitan, karena lintas kementerian, asumsinya guru/pengawas yang diangkat kemenag menjadi kewenangan kemenag memang dinas pendidikan atau Pemda provinsi. Pemda Provinsi Bali belum pernah mengurusnya, kenaikan pangkat dan jabatan fungsional guru/pengawas dari IVb ke IVc yang diangkat oleh Kemenag. Hal ini memang karena belum pernah ada guru agama yang mengajukan untuk diurus kenaikan.

Problem memenuhi persyaratan untuk kenaikan pangkat dirasakan oleh GPA provinsi Bali yang diangkat oleh kemenag karena GPA mengalami kesulitan terkait penulisan karya tulis ilmiah dan keharusan seminar atau uji kompetensi ketika kenaikan pangkat dari IV B ke IV C.

Untuk pengurusan angka kredit di kemendikbud, membutuhkan birokrasi yang panjang dan waktu yang tidak pasti karena terlalu panjang urusannya, maka secara pribadi para kasi kemenag agama Hindu di kota Denpasar mengusulkan supaya PMA tersebut direvisi supaya Tupoksi manajerial. Hendaknya Pengawas Pendidikan Agama diperkuat melalui SE. Ditjen Pendis, untuk tim penilai angka kredit ke IV c bisa dilakukan di Kemenag, tidak melalui kemendikbud, dengan harapan ke depan ada tim penilaian angka kredit IV a ke atas dilakukan di Kemenag Provinsi agar guru tidak mentok di IV.a. 


\section{Kebijakan Kesejahteraan Guru Pendidikan Agama}

Tidak seluruh para pemangku kebijakan paham terhadap peraturan-peraturan terhadap inpassing. inpassing GPA yaitu penyesuaian atau penyetaraan golongan GPA Non PNS setelah mereka mengikuti sertifikasi guru didasarkan kepada Permendikbud no. 38 tahun 2010 Tentang Penyesuaian jabatan Fungsional guru dan Permendikbud No 28 tahun 2014 tentang inpassing Guru Non PNS yang direvisi dengan Permendikbud no. 12 tahun 2016. Ini artinya terkait regulasi inpashing merujuk kepada regulasi tersebut dilakukan oleh Kemendikbud. Adapun para pelaksana yang kebetulan mereka menjalani mereka telah faham karena mereka sudah melakukannya.

Adapun pemahaman peraturan-peraturan yang berkaitan dengan gaji non PNS, pemangku kebijakan dari kemenag hanya tau pada KMA RI Nomor 1 tahun 2018 tentang Insentif bagi guru bukan pegawai Negeri Sipil pada Kementerian Agama, padahal ada kebijakan pemda yang bisa membayar transpor untuk imbalan/gaji bagi guru non PNS.

Dalam implementasinya, di Provinsi Bali untuk guru agama non PNS, namanya GTT (Guru Tidak Tetap) dan ada yang namanya guru kontrak. Mereka itu guru non PNS yang diusulkan Ke Kemendikbud/Pemda Provinsi melalui Gubernur. Para guru agama non PNS yang telah mendapatkan SK dari Gubernur ini, mereka digaji/honornya melalui OJTM (Orang Jam Tatap Muka), maksudnya para guru agama tersebut dibayar Rp.50.000,- perjam tatap muka istilahnya untuk pengganti transportasi. Jadi kalau guru agama tersebut 24 jam, mereka di gaji sebesar Rp. 1.200.000,-, Untuk Guru non PNS termasuk di dalamnya guru agama yang telah mendapatkan SK Gubernur ada 295 orang. Khusus guru agama non PNS yang ada di kota Denpasar terdapat 24 orang dan guru agama di Kab. Badung ada 1 orang mendapatkan SK Gubernur pada tahun 2019 ini dan pada tahun 2017guru agama Kabupaten Badung juga ada beberapa yang diberi SK oeh Gubernur.

Sekolah-sekolah yang berada di Provinsi Bali, beberapa guru agama di sekolah non PNS telah diangkat oleh pemda dan oleh Gubernur diberi SK untuk mendapatkan gaji/honor sebesar OJTM. Ternyata Dalam penyediaan guru Non PNS tersebut Pemda Provinsi Bali telah memperhatikan kesejahteraannya bagi guru tidak Tetap (GTT) tersebut, tanpa pandang guru agama yang mayoritas pemeluk agamanya maupun minoritas pemeluknya. Seperti kasus di SMK Harapan di Kabupaten Badung yang tidak tersedia guru agama pendidikan Islam (PNS), sedangkan siswa muslim sebanyak 300 anak, maka dianjurkan untuk mengangkat guru honorer (GTT) yang diusulkan ke Bupati untuk diberikan gaji/honor dari Pemda Provinsi Bali.

Pemda Provinsi Bali sebenarnya sudah mulai memperhatikan guru agama non PNS di sekolah, namun belum seluruhnya diberi kesempatan untuk terlayani terhadap proses inpashing GPAI (khususnya) Non PNS. Adapun terkait inpashing Guru di lingkungan Kemenag, Menteri Agama telah mengeluarkan KMA NO 116 Tahun 2010 Pasal 6 ayat 6 Guru bukan pegawai negeri sipil di lingkungan kementerian agama yang telah ditetapkan jabatannya melalui inpassing diusulkan oleh kepala madrasah kepada menteri agama melalui kepala kantor kementerian agama kabupaten/kota setempat. Adapun KMA tersebut hanya melayani Guru Non PNS yang mengajar di Madrasah atau Pendidikan Keagamaan yang ada di lingkungan Kemenag.

Begitu juga untuk gaji/honor guru agama non PNS yang dikeluarkan oleh Pemda provinsi Bali, presentasinya porsi guru agama di sekolah masih sedikit apalagi guru agama yang diangkat oleh Kementerian Agama. Kebanyakan guru agama Hindu yang diangkat oleh Pemda atau Dinas Pendidikan yang mendapatkan Honor OJTM.

KMA NO 1 tahun 2018 terkait pembayaran insentif bagi GPA Non PNS di lingkungan Kemenag tidak memasukkan GPA di sekolah umum. Sehingga GPAI khususnya di sekolah umum tidak mendapatkan insentif tersebut. Namun kemudian KMA tersebut di rubah yang mengakomodir GPA di sekolah umum Termasuk di dalamnya Perpres No 154 tahun 2015 tentang Tunjangan Kinerja Pegawai di Lingkungan Kemenag.

Wawancara dengan Kepala Kemenag Kota Denpasar (Komang Sri Marheni, 2012), suntuk haji/honor guru agama Non PNS, Kemenag dhi. Pusat (karena belum otonom), hendaklah mengeluarkan peraturan untuk 
mengangkat guru agama tidak tetap (GTT) atau guru kontrak yang dibayarkan dengan DIPA Kemenag, seperti halnya pemda Bali yang telah mengangkat guru GTT kemudian diberi SK Gubernur dan dibayar dengan OJTM (per tatap Muka/Rp.50.000,- dan diperpanjang setiap tahun. Dan hendaknya KMA No 116 Tahun 2010 harusnya ditambahkan klausul dan untuk Guru Pendidikan Agama di Sekolah Umum.

\section{Kebijakan Rekrutmen Guru Pendidikan Agama}

Para pemangku kebijakan pada dasarnya memahami tentang peraturan-peraturan rekrutmen guru agama. Pengangkatan Guru Pendidikan Agama di provinsi Bali, dilakukan oleh Pemerintah daerah setempat dengan SK Gubernur dan guru honorer (GTT) diangkat oleh Dinas Pendidikan. Dasar Pemda melakukan rekrutmen guru pendidikan Agama yaitu; PP 74 tahun 2008 yang kemudian dirubah menjadi PP 19 tahun 2017. Pasal 24 ayat 1 yang memungkinkan pemda melakukan rekruitmen. "pengangkatan dan/atau penempatan guru yang diangkat oleh pemerintah pusat, pemerintah daerah, dan/atau penyelenggara pendidikan yang diselenggarakan oleh masyarakat dilakukan sesuai dengan ketentuan peraturan perundang-undangan" (pasal 58 peraturan pemerintah no. 74 tahun 2008 tentang guru. Adapun yang dilakukan oleh Kementerian Agama, dasarnya adalah PMA nomor 16 tahun 2010 Pasal 14. Ayat (2) yang menyebutkan bahwa pengadaan guru pendidikan agama di sekolah yang diselenggarakan oleh pemerintah daerah dilakukan oleh menteri dan/atau pemerintah daerah.

Dalam implementasinya, kedua instansi tersebut semuanya semua melakukan rekrutmen merujuk pada peraturan-peraturan (PP dan PMA), dan masing-masing instansi juga mengangkat guru agama baik PNS maupun honor sudah berdasarkan analisis kebutuhan. Keduanya menggunakan mekanisme yang benar, yakni untuk PNS melalui seleksi tes yang dilakukan oleh Dinas Pendidikan Provinsi, bagi guru yang lolos diusulkan ke Badan Kepegawaian daerah (BKD) Provinsi. Setelah di telaah dan memenuhi persyaratan administrasi baru diajukan usulan tersebut ke Badan Kepegawaian Negara (BKN) Pusat.
Adapun Kemendikbud Pusat adalah sebagai penerima tembusannya saja.

Kedua instansi di Kemenag dan Pemda masing-masing memiliki anggaran untuk melakukan rekrutmen guru agama, pemda juga ada kewenangan untuk mengangkat, yang menjadi problem, proses pengangkatan guru pendidikan agama ini tidak pernah berkoordinasi dengan kementerian agama. Karena penafsiran terhadap pasal-pasal tersebut bahwa kewenangan pengangkatan guru agama di kabupaten/kota se Indonesia oleh Bupati/Walikota se Indonesia. Untuk Provinsi Bali sudah memberlakukan beberapa tahun yang mengangkat guru agama adalah Bupati/Walikota. Sehingga data yang ada tentang guru pendidikan agama tidak nyambung/berbeda yang diangkat dari Kemenag dan yang diangkat dari Diknas/ Pemda

Perbedaan data ini tentang guru pendidikan agama yang diangkat oleh pemda dan yang diangkat oleh Kemenag selalu berbeda, menurut Kabid PAKIS Kemenag Prov. Bali, diharapkan ke depan dalam perekrutan Guru agama (semua Agama) Pemda selalu bersinergi dengan kemenag. Perlu koordinasi dalam pengangkatan guru pendidikan agama yang diawali dari pusat yaitu Menteri Agama (Kemenag) dengan Menteri Pendidikan dan Kebudayaan (Kemendikbud) dan koordinasi antar Dirjen dengan Dirjen. Dan untuk terpenuhinya kurangnya guru ini Sementara Kanwil Kemenag Provinsi Bali dan Kemenag tingkat Kota/Kabupaten serta Balai Diklat Keagamaan (BDK) Provinsi Bali hanya mengalokasikan pembinaan kepada GPA sesuai anggaran yang ada. Hal ini disebabkan oleh keterbatasan anggaran baik di Kemenag Kab/Kota maupun Kanwil Kementerian Agama dalam menyelenggarakan Bintek, workshop, dan sosialisasi untuk para guru pendidikan agama di sekolah.

Pembinaan GPA yang dilaksanakan Kemenag antara lain melalui Pembinaan oleh Pengawas PAI, Bimtek Kurikulum 2013, PKB untuk GPAI dan Pengawas PAI, Apresiasi GPAI dan PPAI berprestasi, dan terakhir PPKB (program pengembangan keprofesian berkelanjutan). Walau jumlah GPA dan Pengawas yang telah mengikuti ToT PKB 
jumlahnya masih terbatas. Hal lain yang ditemukan adalah keterbatasan akses internet untuk melakukan assessment atau pretest PPKB berbasis online. Banyak daerah dan GPA yang kesulitan untuk melakukan assessment online karena keterbatasan jaringan dan kemampuan GPA sendiri.

Keterbatasan jumlah pengawas menyebabkan pembinaan dilakukan oleh pengawas sangat terbatas. Coverage areasn pengawas dalam melakukan pembinaan sangat luas dengan jarak yang cukup berjauhan sedang jumlah GPA yang banyak, menyebabkan efektivitas pembinaan hanya bisa dilakukan pada area terbatas.

Pembinaan Guru Pendidikan Agama (GPA) merujuk kepada PP 55 tahun 2007 tentang Pendidikan Agama dan Keagamaan, Pasal 3 ayat 2 "Pengelolaan pendidikan agama dilaksanakan oleh Menteri Agama". Kewenangan pembinaan tersebut termasuk kewenangan pelaksanaan sertifikasi guru Pendidikan agama. Semua terkait pembinaan GPA berada di bawah kewenangan Kemenag, termasuk pemenuhan kekurangan GPA, kurikulum Pendidikan Agama, sertifikasi GPA. Responden baik guru, kasi PAI, Kabid PAI dan Kabid di Dinas Pendidikan memiliki persepsi yang sama bahwa pembinaan GPA ada di bawah Kementerian Agama.

Pembinaan guru agama oleh Kemenag, saat ini dilakukan melalui program PPKB yaitu program pengembangan keprofesian berkelanjutan. Program ini di payungi oleh PMA Nomor 38 tahun 2018 yang mengamanatkan penguatan profesi GPA khususnya GPAI menjadi tanggung jawab Kemenag. Program PPKB ini dilaksanakan secara TSM (terstruktur, sistematis dan masif) oleh Direktorat PAI. Program PPKB ini menyasar kepada kompetensi profesional Pedagogik I dan Pedagogik II (metode dan pembelajaran). PPKB yang dilakukan oleh Direktorat PAI ini menitik beratkan kepada kompetensi Pedagogik 2 yaitu metodologi pembelajaran. Sementara pedagogik 1 terkait profesional dan leadership dan spiritual tidak mendapatkan perhatian yang serius. Sehingga dengan adanya beberapa kendala dalam pembinaan GPA, penulis memberi saran agar lebih efektif yaitu dengan mengaktifkan dan merevitalisasi Kelompok Kerja Guru (KKG) dan Musyawarah Guru Mata Pelajaran (MGMP) di tingkat Kab/Kota, karena menurut beberapa responden, KKG dan MGMP memiliki peran strategis untuk meningkatkan profesionalitas GPA.

\section{Analisis Kebijakan Karir Guru Pendidikan Agama}

Temuan di lapangan menyebutkan responden GPA dan Pengawas memberikan tanggapan bahwa terkait karier GPA, terkendala pada kemampuan GPA dalam menyediakan persyaratan untuk kenaikan pangkat. Khususnya dari III c ke III d, III d ke IV a, IV a ke IV b yang mensyaratkan karya tulis ilmiah (KTI) dan penelitian tindakan kelas atau PTK. GPA kesulitan untuk memenuhi persyaratan tersebut karena keterbatasan kemampuan atau kompetensi dalam melakukan PTK dan menulis karya ilmiah.

Kesulitan dalam memenuhi persyaratan untuk kenaikan pangkat dirasakan oleh GPA yang diangkat oleh Kemenag. Kenaikan pangkat mulai dari golongan III $\mathrm{C}$ dan seterusnya. Dinas Pendidikan dan atau Kemenag mengaku belum pernah menguruskan GPA atau pengawas yang akan naik pangkat dari IV A ke IV B. Hal ini terjadi karena tidak ada GPA yang mengusulkan, yang disebabkan GPA mengalami kesulitan terkait penulisan karya tulis ilmiah dan keharusan seminar atau uji kompetensi ketika kenaikan pangkat dari IV B ke IV C. Hal tersebut mengartikan bahwa kemampuan GPA untuk memenuhi persyaratan administratif Karya Tulis Ilmiah (KTI) dan rendahnya kemampuan GPA dalam menuliskan KTI masih rendah. Seharusnya Pengembangan karier cukup didasarkan kepada: prestasi kerja, mampu mengemban tugas, berakhlak baik dan dapat diterima semua komponen sekolah (Khasani, 2010).

Sementara pembinaan dari Kemenag untuk kompetensi KTI dan PTK sangatlah jarang dilakukan. Bahkan nyaris tidak ada. Khususnya pada tingkat kabupaten/kota. Sementara dari IV b ke IV c dan seterusnya harus uji kompetensi di Kementerian Pendidikan dan Kebudayaan (Kemendikbud). Sementara untuk GPA yang diangkat oleh Pemerintah Daerah (Pemda), karier 
kepangkatan kepegawaiannya langsung ditangani oleh birokrasi pemda setempat. Kondisi ini menimbulkan kekhawatiran akan terjadi stagnasi kenaikan jabatan fungsional guru agama mulai dari jabatan fungsional Guru Pertama Golongan III/b, dan betul-betul akan mengalami kemacetan untuk kenaikan pangkat dan jabatan fungsional pada jenjang yang lebih tinggi lagi.

Persoalan lain dari pengembangan karier GPA adalah, GPA (khususnya yang diangkat Kemenag) sulit untuk mendapatkan akses menjadi kepala sekolah. Menurut salah seorang responden GPA yang diangkat Kemenag, hal yang tidak mungkin GPA Nip Kemenag menjadi kepala sekolah di sekolah umum negeri. Karier di struktural pun juga sulit, karena GPA harus pindah tugas dari tenaga fungsional menjadi tenaga struktural.

Kemampuan guru untuk melakukan memenuhi syarat kenaikan pangkat yang rendah, dikhawatirkan akan Ketentuan ini menimbulkan kekhawatiran, di mana diperkirakan akan terjadi stagnasi kenaikan jabatan fungsional guru mulai dari jabatan fungsional Guru Pertama Golongan III/b, dan betul-betul akan mengalami kemacetan untuk kenaikan pangkat dan jabatan fungsional pada jenjang yang lebih tinggi lagi. Sementara untuk kenaikan pangkat GPA, Masih merujuk kepada regulasi yang sudah ada. Kewenangan kemenag hanya pada sampai penilaian angka kredit kepangkatan IV b. Kemenag belum memiliki instrument dan regulasi yang kuat untuk penilaian angka kredit di atas IV b. Ini juga terkait regulasi yang dikeluarkan oleh MenPan RB terkait penilaian angka kredit.

Permen PAN RB Pasal 23 terkait pejabat penilai angka kredit, kewenangan pejabat penilai yang dimiliki Kemenag hanya menilai pada kenaikan pangkat IV b. Sementara untuk ke IV c sampai dengan IV e harus melalui Kemendikbud. Selain itu Peraturan Pemerintah Nomor 11 tahun 2017 mensyaratkan pengajuan kenaikan pangkat dari IV b ke IV c harus lulus uji kompetensi. Ini artinya untuk kepangkatan Guru PA membutuhkan penguatan melalui KMA atau minimal kebijakan setingkat Direktur Jenderal, terkait pemenuhan pemenuhan aspek manajerial. Selain itu Kemenag segera melakukan koordinasi dengan
Kemendikbud dan Menpan RB terkait mekanisme uji kompetensi bagi GPA yang akan mengajukan kenaikan pangkat dari IV b ke IV c.

\section{Analisis Kebijakan Kesejahteraan Guru Pendidikan Agama}

Minimnya kuota untuk mengikuti Pendidikan Profesi Guru atau PPG menjadi Masalah. Persyaratan mengikuti pretest sebelum mengikuti PPG melalui online menjadi persyaratan untuk mengikuti PPG. Hal lain yang ditemukan adalah minimnya pemenuhan kewajiban 24 jam mengajar di kelas, terutama bagi GPA Islam yang menjadi minoritas di provinsi ini. Kendala lain yang dihadapi dalam masalah sertifikasi adalah seharusnya memiliki SK dari Dinas Pendidikan bagi GPA non PNS. Hal ini cukup memberatkan bagi GPA Non PNS Karena Dinas Pendidikan tidak mau memberikan SK sebagai tenaga honor Farrah sebagai GPA yang di sekolah umum. Sementara untuk GPA Non PNS yang diangkat Yayasan, cukup melampirkan SK Yayasan yang bersangkutan.

Problema lain adalah akses untuk mengikuti sertifikasi terbatas karena minimnya informasi untuk mengikuti pretest. Setelah mengikuti pretest peserta bisa mengikuti Pendidikan Profesi Guru (PPG). Sementara terkait PPG untuk GPA Persyaratan guru bukan PNS di sekolah negeri seperti disebutkan persyaratan PPG, hanya berlaku untuk pendaftaran dan pelaksanaan PPG Dalam Jabatan, tidak berlaku untuk persyaratan pembayaran tunjangan profesi pendidik. Biaya pelaksanaan PPG Dalam Jabatan bagi guru bukan PNS di sekolah negeri menjadi tanggung jawab Pemerintah Daerah atau Satuan Pendidikan, Persoalan lain adalah keharusan mengikuti PPG dalam waktu lama dan meninggalkan tugas mengajar serta harus di lakukan di luar daerah.

Hal lain yang ditemukan di lapangan adalah pembayaran TPG yang selalu "telat" dengan persyaratan yang cukup banyak. Persyaratan mengisi sistem SIAGA, masih mengandalkan pegawai atau staf di Kemenag. Walau sudah mengisi SIAGA, masih saja ada persyaratan administrasi yang harus di penuhi. 
Sementara untuk pembayaran Tunjangan Kinerja, GPA dan Pengawas PAI terancam tidak mendapatkan. Sebab Perpres terkait pembayaran Tukin menyebutkan hanya bagi pegawai yang memberi manfaat langsung kepada Kemenag. Sehingga GPA yang diangkat Kemenag dan mengajar di sekolah umum tidak masuk dalam katagori "memberi manfaat langsung" kepada Kemenag. Selain itu banyak GPAI Non PNS terkendala untuk mengikuti inpasssing, karena terkendala persyaratan di Kemendikbud belum terbuka luas.

Regulasi terkait inpassing GPA yaitu penyesuaian atau penyetaraan golongan GPAI Non PNS setelah mereka mengikuti sertifikasi guru didasarkan kepada Permendikbud no. 38 tahun 2010 Tentang Penyesuaian jabatan Fungsional guru dan Permendikbud No 28 tahun 2014 tentang inpassing Guru Non PNS yang direvisi dengan Permendikbud no. 12 tahun 2016. Ini artinya terkait regulasi inpassing merujuk kepada regulasi tersebut dilakukan oleh Kemendikbud. Problem utama dari persoalan inpassing ini adalah Kemendibud belum memberikan akses yang maksimal untuk melayani terhadap proses inpasshing GPAI (khususnya) Non PNS. Sementara terkait inpassing Guru di lingkungan Kemenag, Menteri Agama telah mengeluarkan KMA No. 116 Tahun 2010 Pasal 6 ayat 6 Guru bukan pegawai negeri sipil di lingkungan Kementerian Agama yang telah ditetapkan jabatannya melalui inpassing diusulkan oleh kepala madrasah kepada menteri agama melalui kepala kantor kementerian agama kabupaten/kota setempat. KMA tersebut hanya melayani Guru Non PNS yang mengajar di Madrasah atau Pendidikan Keagamaan yang ada di lingkungan Kemenag. Sebagai tawaran solusi sebaiknya KMA No 116 Tahun 2010 harusnya ditambahkan klausul dan untuk Guru Pendidikan Agama di Sekolah Umum.

Sementara untuk sertifikasi bagi GPAI Non PNS terkendala dengan Surat Edaran Sekjen Kemendikbud Nomor 088209/A.C5/KP/2011 yang mengharuskan GPA Non PNS memiliki Surat Keputusan dari Bupati/Walikota atau Kepala Dinas. Sesuatu yang di beberapa daerah sulit untuk dipenuhi. Hal ini disebabkan karena Pemda tidak ingin ada tuntutan terkait pengangkatan GPA Non PNS untuk menjadi PNS.

KMA No 1 tahun 2018 terkait pembayaran insentif bagi GPA Non PNS di lingkungan Kemenag tidak memasukkan GPA di sekolah umum. Sehingga GPAI khususnya di sekolah umum tidak mendapatkan insentif tersebut. Namun sebaiknya KMA No 1 tahun 2008 tersebut di rubah KMA no. 27 tahun 2019 bagi guru bukan PNS pada Kementerian Agama dan pada sekolah. yang mengakomodir GPA di sekolah umum. Walau pun pass tataran implementasi belum terealisasi secara maksimal. Artinya belum semua GPA non PNS mendapatkan insentif. Termasuk di dalamnya Perpres No 154 tahun 2015 tentang Tunjangan Kinerja Pegawai di Lingkungan Kemenag, yang memasukkan GPAI yang diangkat Kemenag namun bekerja di Sekolah Umum Negeri atau swasta.

\section{Analisis Kebijakan Rekrutmen Guru Pendidikan Agama}

Responden GPA sebagian besar mengharapkan rekrutmen dilakukan oleh Kemenag agar mudah pembinaannya. Kementerian Agama provinsi Bali tidak melakukan rekrutmen Guru Pendidikan Agama, khususnya Guru Pendidikan Agama Islam pada sekolah. Hal ini terjadi sejak tahun 2010 yang lalu hingga 2019. Perekrutan Guru Pendidikan Agama (Sekolah Umum) di wilayah ini yang dilakukan oleh Pemerintah Daerah. Karena regulasi penetapan GPA bukan lagi di Kemenag, melainkan di Dinas Pendidikan dan Kebudayaan terutama pemerintah daerah.

Karena keterbatasan pemenuhan GPA oleh pemerintah dan kebutuhan tenaga pengajar mata pelajaran Pendidikan Agama, kemudian disiasati dengan mengangkat atau memfungsikan guru umum yang seagama dengan siswa untuk mengajar Pendidikan Agama.

Dalam hal rekrutmen, Kanwil Kemenag Provinsi bali hanya mengikuti regulasi dan aturan dari pusat. "Kanwil tidak bisa melakukan sesuatu terkait rekrutmen, selain apa yang sudah di putuskan atau diatur oleh Pusat, baik soal jumlah atau kuota rekrutmen GPA," Sedang GPA non PNS pada sekolah swasta menjadi kewenangan yayasan, dan untuk GPA non PNS 
pada sekolah Negri menjadi kewenangan Dispendik. Sedangkan untuk pemenuhan kekurangan guru pendidikan agama di Sekolah Swasta, menurut Suprapto umumnya dilakukan secara langsung oleh yayasan/sekolah melalui pengangkatan guru honorer.

Dalam program Penataan dan Pemerataan Guru Pendidikan Menengah, Kementerian Pendidikan dan Kebudayaan, dalam memberikan layanan pendidikan agama adalah dengan mengangkat guru honorer, walau mereka tidak mendapatkan hak-haknya secara penuh. Untuk menanggulangi persoalan kekurangan guru ini pemerintah telah mengeluarkan SKB lima Menteri: Menteri Pendidikan dan Kebudayaan, Menteri PAN \& RB, Menteri Dalam Negeri, Menteri Keuangan dan Menteri Agama. SKB nomor 05/x/PB/2011 tersebut terkait Penataan dan Pemerataan Guru PNS di daerah. SKB ini memberikan panduan dan petunjuk teknis (juknis) terkait analisis kebutuhan guru di daerah untuk semua jenjang.

Rekrutmen Guru Pendidikan Agama merujuk kepada PP No 19 Tahun 2017 sebagai pengganti atas PP No 74 tahun 2008 tentang Guru. Pasal 58 ayat 3 memungkinkan Kemenag melakukan pengangkatan GPA sesuai data kekurangan GPA yang ada dengan memperhatikan kebutuhan mendesak. Namun demikian Pasal 24 ayat 1 yang memungkinkan pemda melakukan rekruitmen. "pengangkatan dan/atau penempatan guru yang diangkat oleh pemerintah pusat, pemerintah daerah, dan/atau penyelenggara Pendidikan yang diselenggarakan oleh masyarakat dilakukan sesuai dengan ketentuan peraturan perundangundangan" (pasal 58 peraturan pemerintah no. 74 tahun 2008 tentang guru.

Rekrutmen Guru Pendidikan Agama juga bisa merujuk kepada PP 55 tahun 2007 tentang Pendidikan Agama dan Keagamaan Pasal 3 ayat 2 Pengelolaan pendidikan agama dilaksanakan oleh Menteri Agama. Dan PMA Nomor 16 tahun 2010 Pasal 14. Ayat (2) yang menyebutkan bahwa pengadaan guru pendidikan agama di sekolah yang diselenggarakan oleh pemerintah daerah dilakukan oleh menteri dan/atau pemerintah daerah.

Hal ini menunjukkan bahwa terkait rekrutmen GPA bisa dilakukan oleh Kemenag dan Pemda dengan persyaratan dan ketentuan yang berlaku. Namun demikian, jika merujuk kepada PP 55 tahun 2007, bahwa Kemenag memiliki kewenangan penuh untuk melakukan pembinaan dan rekrutmen GPA, maka rekrutmen GPA sebaiknya dilakukan oleh Kemenag untuk memudahkan pembinaan. PP No 19 Tahun 2017 sebagai pengganti atas PP No 74 tahun 2008 tentang Guru Pasal 61 memungkinkan guru untuk menduduki jabatan pimpinan tinggi. Hal lain yang harus diperhatikan adalah Kurangnya koordinasi dalam persoalan analisa kebutuhan guru PAI yang perlu diangkat dengan kebijakan pengangkatan dari kedua lembaga tersebut. Kurangnya koordinasi dalam persoalan pengangkatan dengan persoalan penempatan guru yang sudah lulus tes CPNS.

\section{PENUTUP}

Masyarakat Bali mayoritas beragama Hindu $(83,4 \%)$, jumlah lembaga pendidikan sekolah umum (2.591 lembaga), dari seluruh lembaga jumlah siswa yang terbanyak adalah siswa yang beragama Hindu 345.554 (86\%), diikuti Siswa yang beragama Islam $42.490(10$, 1\%), Siswa beragama Kristen 7.833 (2\%), Siswa beragama Katolik 4.064 (1\%), Buddha $2.520(0,6 \%)$ dan Konghucu $53(0 \%)$. Adapun jumlah guru agama PNS di provinsi Bali terbanyak adalah guru agama Hindu ( $89 \%)$, diikuti guru agama Islam $(9,3 \%)$, Kristen $(0,8 \%)$, Buddha $(0,6 \%)$, Katolik $(0,5 \%)$. Dan Konghuchu (0\%).

Terkait kebijakan pembinaan guru agama, di Provinsi Bali belum dilakukan dengan optimal karena terkendala pendanaan dan keterbatasan jumlah pengawas dengan Coverage areasn yang sangat luas dan jarak cukup jauh. Terkait kebijakan karier, di Provinsi Bali baik Dinas Pendidikan dan Kemenag mengaku belum pernah menguruskan GPA yang akan naik pangkat dari IV A ke IV B. Hal ini disebabkan karena GPA mengalami kesulitan terkait penulisan karya tulis ilmiah dan keharusan seminar atau uji kompetensi ketika kenaikan pangkat dari IV B ke IV C.

Terkait kebijakan kesejahteraan, GPA non PNS terkendala mengikuti sertifikasi dan inpassing karena harus menyertakan SK dari Walikota/Bupati dan GPA yang belum 
sertifikasi karena kuota terbatas. Terkait kebijakan rekrutmen guru agama di sekolah, terdapat tiga jenis guru agama yaitu diangkat oleh Kemenag, diangkat oleh Pemda, dan diangkat oleh Dinas Pendidikan. Data tentang guru pendidikan agama yang diangkat oleh Pemda dan yang diangkat oleh Kemenag selalu berbeda.

Dari kesimpulan di atas, penelitian ini menghasilkan beberapa rekomendasi; pertama, Kementerian Agama Provinsi perlu melakukan koordinasi dengan pemerintah daerah dalam pembinaan guru pendidikan agama di Sekolah; kedua, perlu himbauan dari pemerintah pusat kepada setiap daerah untuk melakukan penguatan KKG dan MGMP menjadi Sumber belajar bagi guru pendidikan agama; ketiga, Kemenag pusat, perlu membuatkan pedoman atau panduan dalam rangka penguatan KKG/MGMP dan dibagikan ke daerah-daerah agar dipedomani; Keempat, perlu sosialisasi PMA No. 38 tahun 2018 tentang PPKB, dan pembiasaan bagi GPA untuk dapat menggunakan perangkat teknologi informasi, termasuk penggunaan secara online;. Kelima, hendaknya tim penilaian angka kredit IVa ke atas bagi GPA dilakukan di Kemenag Provinsi; Keenam, hendaknya ketentuan SK Honorer dari Kepala Daerah dapat diturunkan dengan SK Kepala Sekolah atau SK Ketua yayasan. Ketujuh, perlu ke depan dalam perekrutan Guru agama melalui Pemda bersinergi dengan Kemenag. Kedelapan, dalam memenuhi kebutuhan Guru agama, di Sekolah, Kemenag perlu mengangkat guru agama GTT atau guru kontrak yang dibiayai oleh APBN, seperti halnya GTT Pemda Bali yang dibiayai APBD.

\section{UCAPAN TERIMAKASIH}

Terima kasih kepada Kepala Puslitbang Pendidikan Agama dan Keagamaan Badan Litbang dan Diklat yang telah memberi kesempatan kepada penulis untuk meneliti, kepada Kepala bidang Pakis kemenag provinsi Bali, Kepala Dinas Pendidikan dan Pemerintah Daerah Provinsi Bali, Pengawas dan Guru Pendidikan Agama yang telah memberikan data dan informasi. Juga kepada Redaktur Edukasi atas termuatnya tulisan ini, Semoga tulisan ini memberikan wawasan dalam pendidikan agama di Indonesia.

\section{DAFTAR PUSTAKA}

Adamson, F. and Darling-Hammond, L. (2012) 'Funding Disparities and the Inequitable Distribution of Teachers: Evaluating Sources and Solutions', education policy analysis archives, 20, p. 37. doi: 10.14507/epaa.v20n37.2012.

Badan Pusat Statistik Povinsi Bali (2018) Penduduk Provinsi Bali Menurut Agama yang Dianut Hasil Sensus Penduduk 2010, Badan Pusat Statistik.

Badan Pusat Statistik Povinsi Bali (2019) Provinsi Bali Dalam Angka 2019.

Behrstock, E. and Clifford, M. (2010) Ensuring the Equitable Distribution of Teachers: Strategies for School, District, and State Leaders, Education. Washington, DC.: National Comprehensive Center for Teacher Quality.

Buleleng, P. K. (2017) Pengertian, Prinsip dan Penerapan Good Governance di Indonesia, Website Resmi Pemerintah Kabupaten Buleleng. Available at: https://bulelengkab.go.id/detail/artikel/pe ngertian-prinsip-dan-penerapan-goodgovernance-di-indonesia-99 (Accessed: 10 October 2020).

'Evaluasi Kebijakan Pelaksanaan Reward dan Punishment Aparatur Sipil Negara di Kota Bitung' (2019) JURNAL EKSEKUTIF.

Fattah, N. (2012). Analisis Kebijakan Pendidikan, Bandung; Remaja Rosdakarya

Geriani, I. A. K., Suarni, N. K. and Mertasari, N. M. S. (2019) 'Analisis Model Diskrepansi Tentang Program Pendidikan Pembentukan Bintara Polri di SPN Singaraja Tahun Anggaran 2017/2018', 9(1), pp. 13-25.

Grindle, M. S. (2017) Politics and Policy Implementation in the Third World. New Jersey: Princeton Legacy Library.

Hadari, N. (2019) Metode Penelitian Bidang Sosial. 15th edn. Yogyakarta: Gajah Mada University Press.

Hargrove, E. C. (1975) The Missing Link: The 
Study of Implementation. Washington, D.C.: Urban Institute.

Herka Maya, Jatmika, Strategi Peningkatan Kapasitas dan Kompetensi Guru, ppt, Universitas Negeri Jogjakarta.

Hasbullah, H. M. (2015) Kebijakan Pendidikan: dalam Perspektif Teori, Aplikasi, dan Kondisi Objektif Pendidikan di Indonesia. Jakarta: Rajawali Pers.

Hayadin, Juni 2012, Pengelolaan Guru Pendidikan Agama dalam Konteks Desentralisasi Pendidikan, Jurnal Pendidikan dan Kebudayaan, Vol. 18, Nomor 2.

Hayadin, H. O. (2018) 'Indeks Layanan Pendidikan Agama pada SMA dan SMK di 34 Ibu Kota Provinsi', EDUKASI: Jurnal Penelitian Pendidikan Agama dan Keagamaan, 16(1). doi: 10.32729/edukasi.v16i1.458.

Ilham Arisaputra, M. (2013) 'Penerapan Prinsip-Prinsip Good Governance dalam Penyelenggaraan Reforma Agraria di Indonesia', Yuridika, 28(2). doi: 10.20473/ydk.v28i2.1881.

Khasani, A. (2010) Implementasi Manajemen Sumber Daya Guru (Studi Rekrutmen dan Pengembangan Guru PAI SMAN seRayon 11 Jakarta Selatan). IAIN Walisongo. Available at: http://eprints.walisongo.ac.id/163/.

Ma'rifataini, L. D. (2018) 'Artikel Evaluasi Kebutuhan, Penyediaan dan Pembinaan Guru Pendidikan Agama Islam di Sekolah', Penamas, 31(2), p. 433. doi: 10.31330/penamas.v31i2.248.

Mead, L. M. (2015), Teaching Public Policy: Linking Policy and Politics. Journal of Public Affairs Education, 389 (193)
Moh Nazir (1988), Metode Penelitian, Ghalia Indonesia, Jakarta, 27 dan 51

Muadi, S., MH, I. and Sofwani, A. (2016) 'Konsep Dan Kajian Teori Perumusan Kebijakan Publik', Jurnal Review Politik, 6(2), pp. 195-224. Available at: http://jurnalpolitik.uinsby.ac.id/index.ph p/jrp/article/view/90.

Nurudin (2017) Implementasi Kebijakan Pendidikan Agama Hirarki Agama Dalam Negara di Ruang Pendidikan. CV. Baroena Daya.

Program Penataan dan Pemerataan Guru Pendidikan Menengah tahun (2016), Kementerian Pendidikan dan Kebudayaan, Dirjen Guru dan Tenaga Kependidikan

Purnama, S. (2010) Jurnal Manajemen Pendidikan. Malang. Available at: http://digilib.uinsuka.ac.id/19595/1/SIGIT PURNAMA Desain Penelitian Kebijakan Pendidikan.pdf.

Suprapto, 2006, Studi Tentang Pemenuhan Guru Pendidikan Agama di Sekolah (SMP) dalam rangka pemerataan Pelayanan Pendidikan, Puslitbang Penda.

Sutapa, M. (2008) 'Kebijakan Pendidikan dalam Perpektif Kebijakan Publik', Jurnal Manajemen Pendidikan, (2), p. 13. 